\title{
Development of the Rabbit Pancreas with Particular Regard to the Argyrophilic Cells
}

\author{
M. TITLBACH ${ }^{1,2}$, E. MAŇÁKOVÁ ${ }^{1}$ \\ ${ }^{1}$ Charles University Prague, $3^{\text {rd }}$ Faculty of Medicine \\ Centre for Research of Diabetes, Metabolism and Obesity \\ ${ }^{2}$ Charles University Prague, $1{ }^{\text {st }}$ Faculty of Medicine, \\ Institute of Cellular Biology and Pathology \\ Received February 3, 2006 \\ Accepted October 2, 2007
}

\begin{abstract}
Titlbach M., E. Maňáková: Development of the Rabbit Pancreas with Particular Regard to the Argyrophilic Cells. Acta Vet. Brno 2007, 76: 509-517.

The aim of the study was the description of the prenatal development of rabbit pancreas, cell modifications, and changes in their volume and mitotic activity.

Immunohistochemical, light and electron microscopic procedures were employed. Stereological methods were used for estimation of cellular and nuclear volumes. Hits on epithelial cells, tubular lumens, and endocrine progenitor cells were counted by systematic field sampling using test grid. Number of mitoses was registered in various cellular types after colchicine treatment. Data obtained were converted to $1 \mathrm{~mm}^{3}$ tissue.

First granules were observed in cells on day 10 and 18 hours, however two different granular types are distinguishable by electron microscopy only on day 15, when insulin and glucagon can be detected immunohistochemically. Cellular volume increased remarkably in harmony with findings of granules in serous cells. Number of epithelial cells increased also exponentially. The increase was more rapid between days 13 and 15, later it appeared exponential. Value of mitotic index and length of cell cycle did not change considerably between days 15 and 24. Mitoses were observed in ductal, exocrine, as well as endocrine cells. The dividing endocrine cells were those that contained fine dense granules (progenitor cells).

The sub-population of progenitor cells is able to divide, however, this source of cells appears insufficient for exponential growth. Results after colchicine treatment show the increase of cell population but the life-span and a period necessary for volume multiplication vary. Mitoses decrease in both sub-populations during the prenatal period. The progenitor cells arise probably by differentiation from the ducts, because their number increases proportionally to the main cell population.
\end{abstract}

Islets of Langerhans, progenitor cells, exocrine cells, volume, mitosis

Pancreas in animals from fishes to birds develops from one dorsal and two ventral anlagen (left and right), whereas only one dorsal and one ventral anlagen occur in mammals (Brachet 1896; Göppert 1891, 1892; Brouha 1898; Siwe 1926). Pancreatic buds arise from the anlagen supplying epithelial cells for ducts, exocrine, and endocrine cells.

Special cells in pancreas were observed in embryos and in the period early after birth. Laguesse (1895) described the cells as "cellules troubles". These eosinophilic cells with granules were scattered within tubules. Later, Neubert (1926) studied "Mutterzellen"(the "muddy" or progenitor cells) during the islets development. "Progenitor" cells were found within the adjacent epithelial tissue but they have never been found in the tubular lumen so far. They occurred also at the border between epithelial and connective tissue. Protodifferentiated cells described by Pictet and Rutter (1972) and Pictet et al. (1972) in electron microscopy were probably the "progenitor" cells.

The cells with small granules were found by electron microscopy in human foetuses just before birth in addition to typical insular cells (Deconinck et al. 1972). The cells were also 
argyrophilic (Larsson et al. 1976). They were named IV cells and later D1 cells according to Solcia et al. 1973). Titlbach et al. (1985) described similar findings in young lambs early after birth. Large islets were composed almost exclusively of insulin immuno-reactive cells that have small $(195 \pm 27 \mathrm{~nm})$ dense granules in electron microscopy, whereas adult sheep possessed in these cells large granules with a pale core (262 $\pm 62 \mathrm{~nm})$. Cells in large islets were also argyrophilic (after staining according to Grimelius and Wilander). Small dense granules were described earlier by Bonner-Weir and Like (1980).

The present study focused on the rabbit pancreas during prenatal development, on the modification of its cells, and on changes in their volume and mitotic activity.

\section{Materials and Methods}

We used 10 adult rabbit females (Grey Chinchilla; VELAZ Ltd, Prague, Czech Republic) weighing approximately $4 \mathrm{~kg}$ for the study. The animals were bred on standard pellet diet (VELAZ Ltd, Prague, Czech Republic) and water ad libitum, at a temperature of $20{ }^{\circ} \mathrm{C}$, humidity $55 \pm 5 \%$. Principles of laboratory animal care were followed. The embryonic age was counted since 8 hours after mating (Weisbroth et al. 1974). Rabbits were anaesthetized by Thiopental (VUAB, Praha, Czech republic) at a dose of $4 \mathrm{mg} / \mathrm{kg}$. After colchicine treatment (Jelínek and Dostál 1975) of randomly selected embryos or foetuses, the wound was sewed up. Does were sacrificed after $2 \mathrm{~h}$ by intravenous treatment with Thiopental at doses of $60-80 \mathrm{mg} / \mathrm{kg}$.

\section{Light microscopy}

Embryos and foetuses were sampled on day 10 and $10 \mathrm{~h}(6+4$ embryos), day 10 and $18 \mathrm{~h}(5+3$ embryos), day 11 and $14 \mathrm{~h}(6+4$ embryos), day $13(6+4$ embryos), day 15 ( $8+6$ embryos $)$, day $18(4+4$ embryos), day 21 ( 5 +6 foetuses), day 24 ( $8+6$ foetuses) day 27 ( $8+6$ foetuses), and day $30(10+4$ foetuses $)$, for all experiments without sex distinction. Each age group was divided in two: for electron-microscopic and light microscopic observation. Offspring were sacrificed by decapitation. The embryos were fixed and whole-embedded. The pancreases with stomach and a portion of the small intestine of the foetuses on days 15 to 21 and later pancreases themselves were sampled. When needed, dissection was made on fixed tissue; Bouin's fluid was used for fixation. After paraffin embedding, 4 - $5 \mu \mathrm{m}$ serial sections were prepared by the routine method. We stained sections with haematoxylin-eosin, aldehyde fuchsin - trichrome (Gomori 1950), Mallory acid phospho-tungsten-haematoxylin (Gomori 1941), Manocchio reaction for basophilia and metachromasia (Manocchio 1964), staining for masked basophilia (Solcia et al. 1973) and two silver techniques - according to Hellestörm and Hellman (1960), and Grimelius (1961) or Grimelius and Wilander (1980).

Immunohistochemical study

Sections for immunohistochemical study were transferred to slides coated with $0.1 \%$ gelatine in water containing $0.01 \%$ chromium potassium sulphate and dried at $37^{\circ} \mathrm{C}$. After paraffin removal and hydration, the slides were immunostained by the PAP method (Sternberger 1979). Background blocking was performed prior to the incubation with the primary antibody a) using common rabbit or guinea pig serum $(1: 200)$ or b) antibodies that were inactivated by the relevant polypeptide saturation (circa $10 \mu \mathrm{g} / 1 \mathrm{ml}$ ). Methanol with $0.5 \%$ hydrogen peroxide (30 min) was used for the blocking of endogenous peroxidase. Polyclonal primary antibody anti-glucagon and anti-somatostatin (Milab, Malmö, Sweden), anti-insulin, anti-PP and PAP (DAKO, Glostrup, Denmark) were used for the immunostaining of hormone-immunoreactive cells. Dilution of primary antibodies was optimized for the method used. Incubation with primary antibody was carried out for $12 \mathrm{~h}$ at $4{ }^{\circ} \mathrm{C}$. After rinsing in the phosphate buffered saline (PBS; 0.01M, pH 7.4), guinea pig antibodies conjugated with horse-radish peroxidase (USOL, Praha, Czech Republic) were used for the detection (30 $\mathrm{min}$ at room temperature). Visualization was carried out by the $3.3^{\prime}$-diaminobenzidine tetrahydrochloride solution (Fluka, Buchs, Switzerland) containing $0.01 \% \mathrm{H}_{2} \mathrm{O}_{2}$ in the PBS buffer $(10 \mathrm{~min})$. After immunostaining, the sections were counter-stained with haematoxylin.

Photographs were taken for the identification of Grimelius and Wilander argyrophilic cells. Slides were then washed up by KCN water solution $(1 \%)$ till the precipitate was dissolved. Then we detected the hormones immunohistochemically and the same sites were micro-photographed again.

\section{Electron microscopic study}

Tissue was fixed either in $2.5 \%$ glutaraldehyde in phosphate buffer and postfixed in $2 \% \mathrm{OsO}_{4}$, or in $2.5 \%$ glutaraldehyde in phosphate buffer (pH 7.4) according to Millonig (1961), only. Specimens were dehydrated, embedded in Epon-Durcupan ACM (Rodrigues 1967), sliced by ultramicrotome Reichert OmU3, and contrasted with uranyl acetate (Watson 1958) or lead citrate (Reynolds 1963). They were observed in the electron microscope OPTON EM 9S2 and EM109. Semi-thin sections were stained with Azur B $(\mathrm{pH}=8.0)$.

\section{Stereology}

We stained every $10^{\text {th }}$ section with haematoxylin-eosin. Hits on epithelial cell (non-differentiated, differentiated serous, and ductal cells), tubular lumens, and stem cells (early differentiation stages of endocrine cells) were counted by systematic field sampling using test grid (magnification $\times 256$, test field $0.1469 \mathrm{~mm}^{2}, A T=P T \cdot \mathrm{d}^{2}$ ). The 
volume of particular structures was calculated according to the formula:

$\mathrm{V}_{\mathrm{i}}=\mathrm{P}_{\mathrm{i}} \cdot \mathrm{d}^{2} \cdot \mathrm{a}$,

$P_{i}$ - sum of test grid points

$\mathrm{d}^{1}$ - distance between points in test grid

a - distance between sections

If a portion of pancreas was missing, the embryo was excluded from study.

Estimation of cellular and nuclear volume

Sections about $1 \mu \mathrm{m}$ thick were cut from the material embedded in Epon-Durcupan and stained with Azure B. Random selected fields were chosen for sampling. Point numbers were calculated for nuclei and cytoplasm of the non-differentiated or differentiated serous cells (magnification $\times 1600$ ). Number of nuclei in testing field was registered simultaneously $\left(3.90625 \cdot 10-3 \mathrm{~mm}^{2}\right)$. Two fields on each slide were evaluated on up to maximum three sections per embryo, which were selected at a minimum distance of $0.02 \mathrm{~mm}$. Ten to twenty test fields were evaluated for every developmental stage.

Nuclear number (number of cell) in $\mathrm{mm}^{3}$ was estimated from (Weibel and Bolender 1973)

$\mathrm{N}_{\mathrm{Vi}}=1 / \beta \cdot \mathrm{N}_{\mathrm{n}} / \mathrm{A}_{\mathrm{T}} \cdot \mathrm{P}_{\mathrm{T}} / \mathrm{P}_{\mathrm{a}}=\mathrm{N}_{\mathrm{n}}^{3 / 2} /\left(2 \cdot \beta \cdot \mathrm{d}^{3} \cdot \mathrm{P}_{\mathrm{T}} \cdot \mathrm{P}_{\mathrm{a}}\right)$

$\mathrm{N}_{\mathrm{n}}=$ number of nuclear cross-sections on test field;

$\mathrm{P}^{\mathrm{n}}=$ number of points hitting nuclei;

$\mathrm{P}_{\mathrm{T}}^{\mathrm{n}}=$ total sum of points on test field;

$\mathrm{d}=$ distance between two points on test field;

$\beta=$ shape coefficient (for globe $=1.38$ ).

Cell and nucleus volume was estimated from:

$\mathrm{v}_{\mathrm{c}}=\mathrm{V}_{\mathrm{Vc}_{\mathrm{c}}} / \mathrm{A}_{\mathrm{Vc},}, \quad \mathrm{V}_{\mathrm{n}}=\mathrm{V}_{\mathrm{Vn}_{\mathrm{n}}} / \mathrm{N}_{\mathrm{Vc}}$

$\mathrm{V}_{\mathrm{Vc}_{-}}=\left(\mathrm{Vc}_{\mathrm{pn}+\mathrm{pc}}\right) \mathrm{P}_{\mathrm{T}}$ or $\underline{\mathrm{V}}_{\mathrm{Vn}}=\mathrm{P}_{\mathrm{n}} / \mathrm{P}_{\mathrm{t}}$

$\mathrm{N}_{\mathrm{Vc}}=$ number of nuclear cross-sections on test field

$\mathrm{P}=$ number of points hitting nuclei

$\mathrm{P}_{\mathrm{c}}^{\mathrm{a}}=$ number of points hitting cytoplasm;

$\mathrm{P}_{\mathrm{T}}^{\mathrm{c}}=$ total sum of points on test field

Mitotic index and stathmokinetic index

The number of mitoses was registered in various cellular types, especially prophases and metaphases, and separately anaphases and telophases (magnification $\times 720$ ). Data obtained were converted to $1 \mathrm{~mm}^{3}$ epithelial tissue. Colchicine at a dose of 15 to $50 \mu \mathrm{g} / \mathrm{g}$ was given intra-amniotically to randomly selected embryos or foetuses (Jelínek and Dostál 1975). The embryonic and foetal pancreases were removed $2 \mathrm{~h}$ after treatment. Those having a frequency of anaphases and telophases of 3\% or higher were excluded from evaluation because the colchicine concentration was probably too low. Mitotic (MI) a stathmokinetic indexes (SKI) were defined following Lemež and Josifko (1957). The mitotic index characterizes mitotic activity in the whole organ giving percentage of cells of the same type in all phases of mitosis. For calculation of the stathmokinetic index only prophase and metaphase are relevant, because colchicine treatment stops progress of the mitotic division on this level. Since the stathmokinetic index takes into consideration not only the number of cells in division but the duration of colchicine treatment, it was used it for the estimation of mitosis duration $(\mathrm{T})$ :

$\mathrm{T}=\tau \cdot \mathrm{MI} / \mathrm{SKI}$,

( $\tau=$ duration of the colchicine treatment,

$\mathrm{MI}=$ number of cellular divisions $\times 100 /($ number of cells in inter-phases + in mitoses $)$

$\mathrm{SKI}=($ number of prophases + mitoses that were arrested in metaphase $) \times 100 /($ number of cells in interphase + mitoses).

\section{Results}

Morphology

Dorsal anlagen were visible in the intestinal wall as a small group next to the columnar epithelium on day 11 (exactly 10 days and 10 hours). Cells containing many glycogen granules, few lipid droplets, few mitochondria and sparse rough endoplasmic reticulum (RER) in cytoplasm showed many mitotic figures. The nucleus was large in comparison with the total cell volume. Small nucleoli were present in almost all nuclei. Some cells contained filament bundles. We did not observe any granules in pancreatic cells.

First small dense granules of the size of approximately $120 \pm 25 \mathrm{~nm}$ were visible later on day 11 (exactly 10 days and 18 hours). Their core was dense without a pale halo between the membrane and the core. Granules were located on the cell periphery. Sparse RER but almost no Golgi apparatus occurred, having been replaced by few smooth membranes. Dorsal anlagen exhibited lumen communicating with the intestine. Nuclei were large, small 
nucleoli were constantly distinct. Mitoses are visible in the non-differentiated cell (Plate V, Fig. 1). Lipid droplets and glycogen were visible in few cells, only (Plate V, Fig. 2).

On day 12 (exactly 11 day and 14 hours), dorsal anlagen protruded from the intestinal wall, forming cords detached by thin lumens. Cells in cords were dense, whereas those lying at the end of tubules were lighter (Plate VI, Fig. 3). Ultra-structurally, cells in cords possessed sparse glycogen granules and lipid droplets, whereas cells forming terminal portion of ducts held no glycogen. Many free ribosomes and polysomes, rough endoplasmic reticulum (containing precipitate), Golgi apparatus as well as numerous dense granules, approximately $145 \pm 35 \mathrm{~nm}$ in diameter without any light halo, were visible in these cells. Bundles of fibrils were present in some cells. No insulin- or glucagon-immunoreactive cells could be detected in the pancreas.

Cells detected by the method according to Grimelius or Grimelius and Wilander were not observed until day 13. Then infrequent insulin- and glucagon-immunoreactive cells were detected, however, we were not able to demonstrate co-localization of argyrophilia and hormone-immunoreactivity. Ultra-structurally, small groups of cells with fine dense granules were found seldom in slides.

On day 15, dorsal and ventral anlagen fused together. Two cellular types, the first containing no granules and the second comprising granules, were found in the pancreas. Cells containing no glycogen and only rare lipid droplets possessed many junctions in the apex, numerous mitochondria and RER. Other cells forming small groups contained two granule types in the basal portion; the first having a diameter of $155 \pm 35 \mathrm{~nm}$, the second having a diameter of approximately $190 \pm 45 \mathrm{~nm}$. Both were round and dense, only few granules exhibited pale halo surrounding a dense core. Some granules were hormone-immunoreactive and stainable by silver method according to Grimelius, others not. All insulin-immunoreactive cells were silver-stainable according to Grimelius, but these cells were rare. On the other hand, only few glucagon-immunoreactive cells were detectable by this method. One or two large tubules were found composed almost only of argyrophilic cells.

On day 18, only two types of granules were found in cells ultra-structurally as in the previous stage. Sparse serous granules were present in the acinar cells. Numerous tubules with more frequent argyrophilic cells (according to Grimelius and Wilander) appeared. While individual cells were present on day 15, many small and few larger groups were visible now. Almost all groups occurred in the tubular walls or in their close neighbourhood. Cells after silver bleaching were rather glucagon- than insulin-immunoreactive (Plate VI, Fig. 4a). Few cells were stained by the method according to Manocchio, or they were metachromatic and somatostatin-immunoreactive. The cells were not stainable by the method according to Hellman and Helleström. One or two tubules containing argyrophilic and/or argyrofobic cells were found. Somatostatin-immunoreactive cells were argyrophobic in one case and argyrophilic in other cases. We were not able to detect any PP cells.

Ultra-structurally, we observed remarkable changes on day 21. Cells with a relatively light cytoplasm, long cisternae of RER and fine dense granules $(150 \pm 40 \mathrm{~nm})$ appeared in the pancreas. Some cells possessed small glycogen particles. In addition to these cells, we observed others with granules of variable size $(185 \pm 50 \mathrm{~nm})$ and density. The cells contained also fine bundles of filaments. The third cellular type comprised granules at their base; the granules were the largest $(215 \pm 45 \mathrm{~nm})$, round, and their core was dense, usually reaching the membrane. The fourth cellular type differed from those mentioned above in the shape of granules. They were not round, their core was lighter and always reached the cover-membrane. Their size was approximately $185 \pm 60 \mathrm{~nm}$. The granules were located markedly often under the plasmalemma. Cells contained numerous mitochondrias and lysosomes. Serous cells were characteristic when observed under electron microscopy. Their granules were frequently large, not round, and located in the cell apex next to the lumen. Cytoplasm contained sparse glycogen granules, but RER was infrequent. 
Many argyrophilic (according to Grimelius and Wilander) cells occurred in tubules but also within acini. The majority of cells were scattered, only few formed small groups. Two large groups of eosinophilic and simultaneously argyrophilic cells were observed in this stage, however, single eosinophilic (progenitor) cells disappeared slowly. Cells stainable according to Solcia et al. or according to Manocchio were more frequent than on day 18. We were able to demonstrate the first positive results using the silver method according to Hellman and Hellerström. The majority of insulin-immunoreactive cells were still argyrophilic (Plate VII, Fig. 4b) but glucagon-immunoreactive cells were argyrofobic. Somatostatin-immunoreactive cells were frequent and always argyrofobic when Grimelius and Wilander method was used, whereas they were argyrophilic according to Hellman and Helleström.

All cell types were distinguishable under electron microscopy on day 24. Relatively less frequent were cells with fine dense granules of size $185 \pm 50 \mathrm{~nm}$. On the other hand, the number of cells with numerous cisternae of RER and mitochondria increased. Smaller granules with a dense core predominated in one cell, the others possessed granules with a light core. However, both granule types were mixed in many cells. A light halo surrounding the dense core was present in a majority of granules of a standard size of $240 \pm 40 \mathrm{~nm}$. They resembled $\beta$-granules in adult rabbits. Less frequent cells were often single contained round moderately large granules $(190 \pm 35 \mathrm{~nm})$ with a dense core that was separated from the cover-membrane by narrow but distinct light space. The granules were mostly accumulated in a small area, the remaining cytoplasma contained mitochondria and RER. The fourth cellular type was found within islets but also separately in the tissue. The granules were numerous, scattered either over the cytoplasm or under the plasmalemma. They did not vary from the above mentioned ones in size $(190 \pm 40 \mathrm{~nm})$ but in shape and density. The majority of granules were not round; the core was lighter without a light halo. Cytoplasm was rich in polysomes.

The acini became larger, mesenchymal tissue diminished. Compact groups of cells grew from acini in many places. Particular cellular types were identified by aldehyde fuchsin trichrome staining. All the above-mentioned staining methods gave positive results as well as the immunohistochemical detection of insulin, glucagon, and somatostatin. However, many insulin- and some glucagon-immunoreactive cells were argyrophobic. The same findings were valid for all somatostatin-immunoreactive cells, too.

On day 27, cells with fine dense granules diminished in electron microscopic picture, although cells with a low degree of differentiation were still present. On the other hand, cells possessing large granules with a light core increased in number. Cells containing a mixture of granules were frequent. Two other cellular types that were mentioned on day 24 were present, too (Plate VII, Fig. 5). Mitoses in the exocrine cell were found only sporadically. Endocrine cells formed clusters that prevailed in contact with exocrine tissue. Cells in the centre of acini were free of serous granules with light cytoplasm without RER - centroacinar cells. Cells were stainable by the classical histological methods. Approximately $50 \%$ of cells were simultaneously argyrophilic and insulin-immunoreactive. However, some of the argyrophobic cells were glucagon- or somatostatin-immunoreactive.

On day 30, there were no substantial ultra-structural changes in comparison with the previous stage. Cells with fine dense granules or cells with variable density and size of granules were still present. More islets lost their contact with the exocrine tissue. However, they still lacked the characteristic adult organization forming compact epithelial groups without capillaries entering the centre. Islets of Langerhans varied morphologically from the adult, being composed of a compact mass of cells without any capillaries. The most important finding was a decreased number of Grimelius-argyrophilic cells caused by the decrease of cells giving insulin-immunoreactivity. In contrast to the previous stage, the majority of insulin-immunoreactive cell were argyrofobic. Glucagon-immunoreactive cell 
Table 1. Coincidence of argyrophilia and insulin-immunoreactivity in pancreatic cells

\begin{tabular}{|c|r|r|r|r|}
\hline Age & No. & Ins+/Arg+ & Ins-/Arg+ & Ins-/Arg- \\
\hline 21 ed & 6 & $20.5 \pm 6.2$ & $35.3 \pm 5.6$ & $44.2 \pm 3.5$ \\
\hline $24 \mathrm{ed}$ & 11 & $8.2 \pm 1.6$ & $40.6 \pm 2.5$ & $51.2 \pm 2.6$ \\
\hline $27 \mathrm{ed}$ & 3 & $0.7 \pm 0.7$ & $45.7 \pm 4.5$ & $53.6 \pm 5.1$ \\
\hline
\end{tabular}

Number of cells being simultaneously argyrophilic and giving reaction on insulin decrease during last days before birth. It is the main reason why number of argyrophilic cells decrease.

Table 2. Growth of exocrine and endocrine epithelial cells; growth of lumens and growth of weight

\begin{tabular}{|c|c|c|c|c|c|}
\hline Day/n & $\begin{array}{c}\text { Epithel. exo- } \\
\text { mean }\left(\mathrm{mm}^{3}\right)\end{array}$ & $\begin{array}{c}\text { Epithel. endo- } \\
\text { mean }\left(\mathrm{mm}^{3}\right)\end{array}$ & $\begin{array}{c}\text { Lumens (ducts) } \\
\left(\mathrm{mm}^{3}\right)\end{array}$ & Day/n & Weigh mean $(\mathrm{g})$ \\
\hline $13 / 4$ & 0.00788 & 0.00085 & 0.00025 & & \\
\hline $15 / 11$ & 0.04442 & 0.00559 & 0.00134 & $15 / 18$ & 0.49 \\
\hline $18 / 11$ & 0.16389 & 0.01494 & 0.01446 & $18 / 19$ & 1.82 \\
\hline $21 / 16$ & 0.69029 & 0.04470 & 0.02631 & $21 / 22$ & 5.26 \\
\hline $24 / 11$ & 3.03054 & 0.22333 & 0.07738 & $24 / 20$ & 14.18 \\
\hline $\mathrm{k}$ & 0.208216 & 0.181282 & 0.195566 & $\mathrm{k}$ & 0.219833 \\
\hline $\mathrm{q}$ & 7.647579 & 6.747412 & 6.127105 & $\mathrm{q}$ & 8.173119 \\
\hline $\mathrm{r}$ & 0.9983 & 0.9929 & 0.9973 & $\mathrm{r}$ & 0.9764 \\
\hline
\end{tabular}

Equation for weight $=0.212 \mathrm{x}+8.173$

Equation for growth of exocrine epithelium $y=0.208 x+7.647$

Equation for growth of endocrine epithelium $\mathrm{y}=0.181 \mathrm{x}+6.747$

Equation for growth of lumens $\mathrm{y}=0.196 \mathrm{x}+6.1237$

Exponential growth $\left(\mathrm{y}=\mathrm{k}^{\mathrm{x}} ; \mathrm{y}=\mathrm{k}^{\mathrm{x}}+\mathrm{q}\right)(\mathrm{r}=$ probability $)$

Body weight, volume of exocrine (exo), endocrine (endo) cell, and lumens increase exponentially during prenatal life. The number of exocrine cells is lower on day 13 but it grows exponentially between day 15 and 24 . The data indicate that variation is maximal on day 13 .

were predominantly Grimelius-argyrophilic (Table 1).

\section{Stereology}

The curve describing the organism growth is S-shaped, or using a logarithmic formula $(\log y=x \cdot \log k+z)$ exponential. We evaluated weight of the control in every stage. They were compared with those used for stereological estimation. Mean weight in control did not differ significantly. The growth of the body mass as well as the volume of exocrine cells, endocrine cells, and ductal lumens was exponential (Table 2). The volume of the cell population grew exponentially, with a constant increase between days 15 and 24. Progenitor cell subpopulation forming approximately $10 \%$ of the pancreatic anlagen increased this way, too. The nuclear volume was remarkably constant, however, the cellular volume increased in association with cell differentiation characterized by numerous granules in serous cells.

Values of mitotic and stathmokinetic indexes stagnated between days 15 and 24, which was in concordance with the above-mentioned findings. Both indexes were approximately $2 \%$. Duration of endocrine cell division was near to the treatment period, being $100 \mathrm{~min}$ on average. Both indexes were lower in the exocrine cells. Estimation of mitosis duration in exocrine cells was approximately $140 \mathrm{~min}$.

\section{Discussion}

Old empirical silver methods of stained chemical substances of that time are unknown. The first Masson's method used ammonium silver and sodium thiosulfate for detection of aldehydes and biogenic amines in cells. The second method uses also ammonium 
silver but reduction is performed by hydroquinone or pyrogalol. Moreover, presumably it detects granules (A-cells, D-cells) that contain the peptide-carrier, chromogranin A and chromogranin B (Varndell et al. 1985; Lukinius et al. 2003). We indicated changes of argyrophilia during prenatal life in dependence on differentiation. Cells in early rabbit embryos, similar to those in early sheep embryos, were argyrophilic in case of insulinimmunoreactivity, whereas glucagon-immunoreactive cells were argyrofobic. These findings are in contradiction with observations in more advanced prenatal stages, newborn and adult animals. Argyrophilic cells detected by the method according to Hellman and Hellestörm contained exclusively somatostatin. When argyrophilic cells were analyzed chemically, the method according to Hellman and Hellestörm was never used (Lunqvist et al. 1990). We confirmed the coincidence of argyrophilia with insulin-immunoreactivity in a significant number of cells. We were able to distinguish only two exocrine cell types in the electron microscope, that varied only minimally, namely in granule size. It may be explained by the very low number of somatostatin-immunoreactive cells on embryonic day 18 . The appearance of pancreatic tissue changed substantially on day 21 . The tubular anlagen developed in the tubo-alveolar gland. The compact epithelial groups sprouted out. Serous cells with granules occurred sporadically. Single argyrophilic cells were present in the tubular wall as well as in primitive alveoli. Hormone detection showed that the majority of glucagon- and somatostatin-immunoreactive cells were argyrofobic, however, $50 \%$ argyrophilic cells were insulin-immunoreactive. This proportion changed markedly with age. Later, only $25 \%$ argyrophilic cells were simultaneously insulin-immunoreactive; on the other hand, $2 / 3$ cells were argyrofobic. The majority of glucagon-immunoreactive cells were argyrophilic. Changes in staining with the classical method occurred together with the modification of the affinity to silver. Aldehyde fuchsin stainable cells appeared first on day 21. Their number increased rapidly, which is in agreement with Bencosme et al. (1970). Ultra-structurally, cells with larger light granules occurred or two granular types were present in one cell that was typical for B-cell maturation (Lukinius et al. 1992).

This process is not restricted to the development in rabbits and supports our observation in sheep or the description of bovine pancreas (Bonner-Weir and Like 1980). Cells with fine dense granules $(140 \pm 190 \mathrm{~nm})$ without a light halo appear in mammals, including humans. They are argyrophilic according to Grimelius (Larsson and Hougaard 1994), however, their hormone content has been so far unknown. The presence of argyrophilic insulinimmunoreactive cells (with fine dense granules in EM) in 30-day-old embryos explains the rapid increase in B-cell number during the late prenatal period in mice and rats (Freie et al. 1975; McEnvoy and Madson 1980). The amount of cells is substantially higher than may be explained by their mitotic activity (Eriksson and Swenne 1982). Mitoses are rare in adult humans and animals but they are more frequent in embryos. Higher frequency may be found in an experiment; after sulphonylurea treatment (Kracht 1958), extensive pancreatomy (Sharma et al. 1999), and also after aloxane treatment (Cavallero 1947; Pictet and Rutter 1972). Our observation in the rabbit was completely in agreement. The successive differentiation of cells with fine, dense granules is probably the main source for acquisition of B-cells during the prenatal period because their mitotic activity is not satisfactory for the physiological need. Stefan et al. (1983) supported the hypothesis that also A-cells develop consecutively because gene expression during early development is common for differentiation of pancreatic cells (Kritik et al. 1999). However, the ventral and dorsal anlagen vary markedly in gene expression and signalling (Kim et al. 1997; Edlund 2001). Mitoses in insular cells were not found, except for the embryonic period and regeneration. Later, mitoses were assigned to B- and agranular cells (Boquist and Emdin 1985). We observed mitoses in ductal, exocrine, as well as endocrine cells, however, they were cells with fine dense granules, only. It signalizes that the subpopulation of progenitor cells is able to divide but the source of cells is not sufficient for an exponential growth. 
Lukinius et al. (2003) provided evidence that progenitor cells in human and swine foetuses contained also multi-hormone granules (glucagon, insulin, somatostatin and pancreatic polypeptide). They were found even in newborn pigs, but adult animals comprised only mature granules. Other authors (De Krijger et al. 1992; Lukinius et al. 1992; Polak et al. 2000) came to a similar conclusion: one granule may contain several hormones or enzymes (Bendayan 1984). Cells containing granules with a light core appeared consecutively. We observed two populations of granules in the same cells especially in later stages. It probably documents the development and maturation of endocrine cells.

Morphology of foetal islets does not correspond to adult ones in rabbits, either. Rebuilding is necessary after birth. Large "Blutinsels" disappear after few days and smaller islets composed from four cellular types remain. PP-immunoreactive cells were not observed before birth.

Data concerning the proliferative activity in stem cells signalize that the subpopulation of new cells is able to divide but the source of cells is not sufficient for an exponential growth. The stem cells arise probably by differentiation, because the total number of endocrine cells increases proportionally to the main cell population but the number of mitoses decreases in both subpopulations during the foetal period. Our findings are in agreement with these conclusions. Successive differentiation of undifferentiated cells in ducts or cells with fine dense granules in an ultra-structural picture is probably the main source of B-cells.

\section{Vývoj pankreatu králíka se zvláštním zřetelem k argyrofilním buňkám}

Cílem práce bylo popsat prenatální vývoj králičího pankreatu, modifikací buněk a změn v jejich objemu a mitotické aktivitě pomocí imunohistochemie, světelné a elektronové mikroskopie. Stereologické metody byly užity pro odhad objemu buněk a jejich jader. Byly počítány zásahy do epitelových buněk, lumen tubulů a endokrinních kmenových buněk užitím testovací mřížky na systematicky vybraných vzorcích. V různých buněčných typech byl počítán počet mitos po aplikaci kolchicinu. Data byla převedena na $1 \mathrm{~mm}^{3}$. Buněčný objem zřetelně vzrůstá s výskytem granul v serosních buňkách. Rovněž počet epitelových buněk vzrůstá exponenciálně. Hodnoty mitotického a stathmokinetického indexu se mezi 15 a 24 dnem stagnují. Mitosy byly pozorovány v duktálních, exokrinních i endokrinních buňkách. Dělící se endokrinní buňky obsahují většinou malá hustá granula (progenitorové buňky). Sub-populace progenitorových buněk je schopna se dělit, avšak tento zdroj není postačující pro exponenciální růst. Výsledky po aplikaci kolchicinu ukazují růst buněčné populace, avšak délka života a doba nutná pro znásobení objemu se liší. Počet mitos po celou dobu fetálního života klesá. Progenitorové buňky pravděpodobně vznikají diferenciací z duktů, protože počet progenitorových buněk klesá proporcionálně s hlavní populací.

\section{Acknowledgement}

We thank Prof. Richard Jelínek for his help and useful comments and Prof. Ivan Raška. The work was supported by the Ministry of Education, Youth and Sports of the Czech Republic (Grant No. MSM 0021620814, MSM 0021622806 and LC 535).

\section{References}

BENSCOME SS, WILSON MB, ALEYASSINE H, DE BOLD J, DE BOLD M 1970: Rabbit pancreatic B-cells. Morphological and functional studies during embryonic and postnatal development. Diabetologia 6: 339-411

BONNER-WEIR S, LIKE AA 1980: A dual population of islets of Langerhans in bovine pancreas. Cell Tissue Res 206: 157-170

BOQUIST L, EMDIN SO 1985: Histochemistry and electron microscopy of islets. In: VOLK BW, ARQUILLA ER (Eds.): The Diabetic Pancreas. $2^{\text {nd }}$ ed. Plenum Medical Book Comp, New York, pp. 127-169

BRACHET A 1896: Recherches sur le développement du pancréas et du foie (selaciens, reptiles, mammiférres). J Anat Physiol 32: 620-696

BROUHA M 1898: Sur les premieres phases du développement du foie et sur l'évolution des pancréas ventraux, chez les oiseaux. Anat Anz 14: 234-242

CAVALLERO C 1947: Application de la méthode colchicinique a létude de diabète alloxanique chez le rat. Rev Belge Path Méd Expér 18: 323-329 
DECONINCK JE, VAN ASSCHE FA, POTVLIEGE PR, GEPTS W 1972: The ultrastructure of the human pancreatic islets. II. The islets of neonates. Diabetologia 8:326-333

DE KRIJGER RR, AANSTOOT HJ, KRANENBURG G, REINHARD M, VISSER WJ, SWENNE I, ERIKSSON U 1982: Diabetes in pregnancy: Islet cell proliferation in the fetal rat pancreas. Diabetologia 23: 525-528

EDLUND H 2001: Factors controlling pancreatic cell differentiation and function. Diabetologia 44: 1071-1079

ERIKSSON U, SWENNE I 1982: Diabetes in pregnancy: Growth of the fetal pancreatic B cells in the rat. Biol Neonate 42: 239-244

FREIE HMP, PASMA A, BOUMAN PR 1975: Quantitative analysis of pancreatic islets development and insulin storage in the foetal and newborn rat. Acta Endocrinol 80: 657-666

GOMORI G 1941: Observations with differential stains on human islets of Langerhans. Am J Pathol 17: 395-409

GOMORI G 1950: Aldehyde-fuchsin: a new stain for elastic tissue. Am J Clin Pathol 20: 665-666

GÖPPERT E 1891: Die Entwicklung und das spätere Verhalten des Pankreas der Amphibien. Morph Jb 17: $100-122$

GÖPPERT E 1892: Die Entwicklung des Pankreas der Teleostier. Morph Jb 20:90-111

SIWE SA 1926: Pankreasstudien. Gegenbaurs Jb 57: 84-307

GRIMELIUS L 1968: A silver nitrate stain for $\alpha_{2}$ cells in the human pancreatic islets. Acta Soc Med Ups 73: 243-270

GRIMELIUS L, WILANDER E 1980: Silver stains in the study of endocrine cells of the gut and pancreas. Invest Cell Pathol 3: 3-12

HELLMAN B, HELLERSTRÖM C 1960: The islets of Langerhans in ducks and chickens with special reference to the argyrophil reaction. Z Zellforsch 52: 278-290

JELÍNEK R, DOSTÁL M 1975: Inhibitory effect of corticoids on the proliferative pattern in mouse palatal processes. Teratology 11:193-8

KIM SK, HEBROK M, MELTON DA 1997: Notochord to endoderm signaling is required for pancreas development. Development 124: 4243-4252

KRITIK MR, JONES E, CHEM Z, KRAKOWSKI M, KRAHL T, GOOD A, WRIGHT B, FOX H, SARVETNICK A 1999: PDX-1 and Msx-2 expression in the regenerating and developing pancreas. J Endocrinol 163: 523-530

LAGUESSE E 1895: Recherches sur l'histogénie du pancreas chez le mouton. J Anat Physiol 31: 475-500

LARSSON L-I, HOUGAARD DM 1994: Coexpression of islet hormones and messenger RNAs in the human foetal pancreas. Endocrine 2: 759-765

LARSSON LI, SUNDLER F, HÅKANSON R 1976: Pancreatic polypeptide - A postulated new hormone: Identification of its cellular storage site by light and electron microscopic immunocytochemistry. Diabetologia 12: $211-226$

LEMEŽ L, JOSÍFKO M 1957: Kvantitativní analysa kombinovaného růstu počtu buněk embryonálního orgánu mitosami jeho základu a buněčnou imigrací či amitosou. Folia Morphol Prague 5: 292-303

LUKINIUS A, ERICSSON JL, GRIMELIUS L, KORSGREN O 1992: Ultrastrustural studies of the ontogeny of fetal human and porcine endocrine pancreas, with special reference to co-localisation of the four major islet hormones. Develop Biol 153: 376-385

LUKINIUS A, STRIDSBERG M, WILANDER E 2003: Cellular expression and specific intragranular localization of chromogranin A, chromogranin B, and synaptophysin during ontogeny of pancreatic cells: an ultrastructural study. Pancreas 27: 38-46

LUNQVIST M, ARNBERG H, CANDELLA J, MALMGREN M, WILANDER E, GRIMELIUS L, OBERG K 1990: Silver stains for identification of neurocrine cells. A study of the chemical background. Histochem J 22: 615-623

MANOCCHIO I 1964: Metacromasia e basofilia della cellule insulari alfa nel pancreas di mammiferi dopo metilazione e demetilazione. Arch Vet Ital 15: 3-7

MC ENVOY RC, MADSON KL 1980: Pancreatic insulin-, glucagons-, and somatostatin-positive islet cell populations during the perinatal development of the rat. II. Changes in hormone content and concentration. Biol Neonate 38: 255-259

MILLONIG G 1961: Advantage of a phosphate buffer for OsO4 solutions in fixation. J Appl Phys 82: 1637

NEUBERT K 1926: Beiträge zum mikroskopischen Aufbau und zur Entwickung des menschlichen Pankreas. Anat Anz (Erg-Heft) 61: 243-248

PICTET R, RUTTER W 1972: Development of the embryonic endocrine pancreas. In: STEINER DF, FREINK A (Eds.): A Handbook of Physiology. Vol. I. Endocrine Pancreas. Williams and Wilkins, Baltimore, pp. 25-66

PICTET R, CLARK WR, WILLIAMS RH, RUTTER WJ 1972: An ultrastructural analysis of the developing embryonic pancreas. Develop Biol 29: 436-467

REYNOLDS RS 1963: The use of lead citrate at high $\mathrm{pH}$ as an electron-opaque stain in electron microscopy. J Cell Biol 17: 208-212

RODRIGUES TG 1967: Ultrastructural changes in the mouse exocrine pancreas induced by prolonged treatment with actinomycin D. Ultrastruct Res 19: 116-129 
SHARMA A, ZANGEN DH, REITZ P, TANEJA M, LISSAUER ME, MILLER CP, WEIR GC, HABENER JF, BONNER-WEIR S 1999: The homeodomain protein IDX-1 increases after an early burst of proliferation during pancreatic regeneration. Diabetes 48: 507-513

SOLCIA E, PEARSE AGE, GRUBE D, KOBAYASHI S, BUSSOLATI G, CREUTZFELDT W, GEPTS W 1973 : Revised Wiesbaden classification of gut endocrine cells. Rendiconti Gastroenterologica 5: 13-16

STEFAN Y, GRASSO S, PERRELET A, ORCI L 1983: A quantitative immunofluorescent study of the endocrine cell populations in the developing human pancreas. Diabetes 32: 293-301

STERNBERGER LA 1979: Immunocytochemistry. $2^{\text {nd }}$ ed. J. Wiley and Sons, New York

TITLBACH M, FÄLT K, FALKMER S 1985: Postnatal maturation of the islets of Langerhans in sheep. Light microscopic, immunohistochemical, morphometric, and ultratructural investigations with particular reference to the transient appearance of argyrophil insulin immunoreactive cells. Diab Res 2: 5-15

VARNDELL IM, LLOYD RV, WILSON BS, POLAK JM 1985: Ultrastructural localization of chromogranin: a potential marker for the electron microscopical recognition of endocrine cell secretory granulas. Histochem $\mathrm{J}$ 17: 981-992

WATSON ML 1958: Staining of tissue sections for electron microscopy with heavy metals. J Biophys Biochem Cytol 4: 475-478

WEIBEL ER, BOLENDER RP 1973: Stereological techniques for electron microscopic morphometry. In: HAYAT MA (Ed.): Principles and Techniques of Electron Microscopy Vol 3. Van Nostrand Reinhold Company, New York, $237 \mathrm{p}$.

WEISBROTH SH, FLATT RE, KRAUSS AL (Eds) 1974: The biology of the laboratory rabbit. Academic Press, New York, pp. 73-90 
Plate V

Titlbach M., Maňáková E.: Development of the ... pp. 509-517

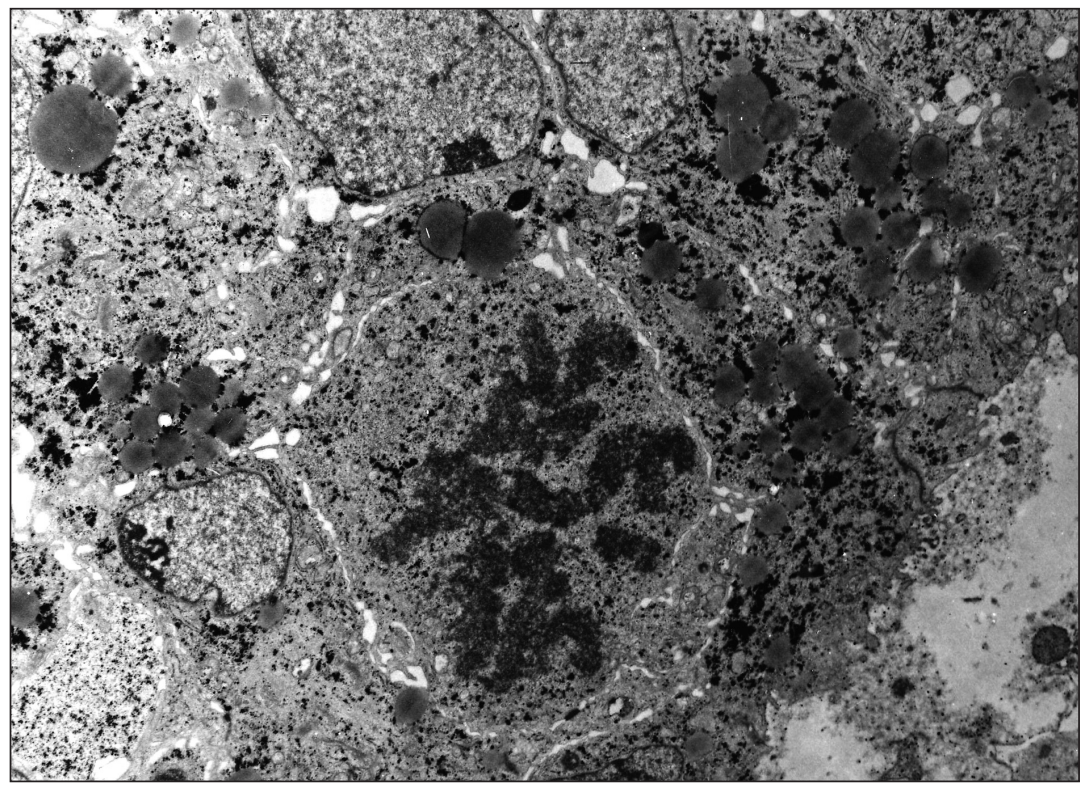

Fig 1. Rabbit $10 \mathrm{~d} 18 \mathrm{~h}$. Mitosis in non-differentiated cell in pancreatic anlagen. Adjacent cells comprise lipid droplets and glycogen granules. Electron microscopy. Magnification $\times 10000$

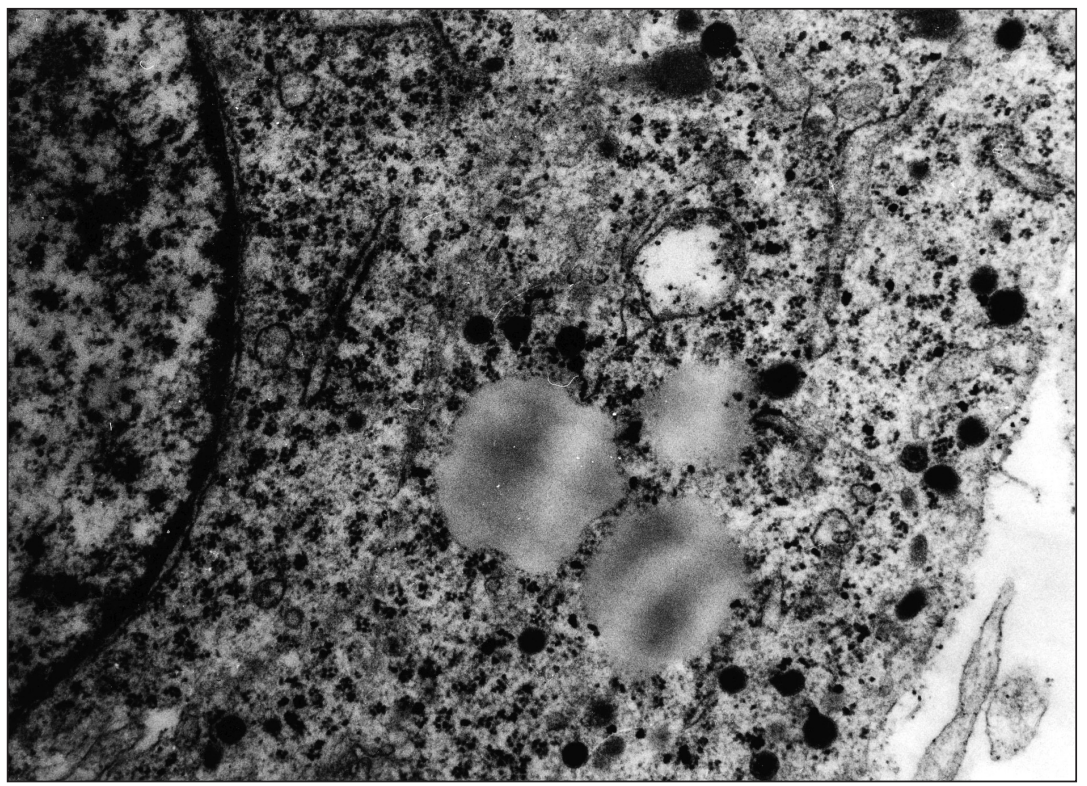

Fig. 2. Rabbit 10 d 18 h. Lipid droplets and glycogen granules are visible only in few cells comprising dorsal anlagen. Small, dense granules are present in cell cytoplasma. Electron microscopy. Magnification $\times 30000$ 


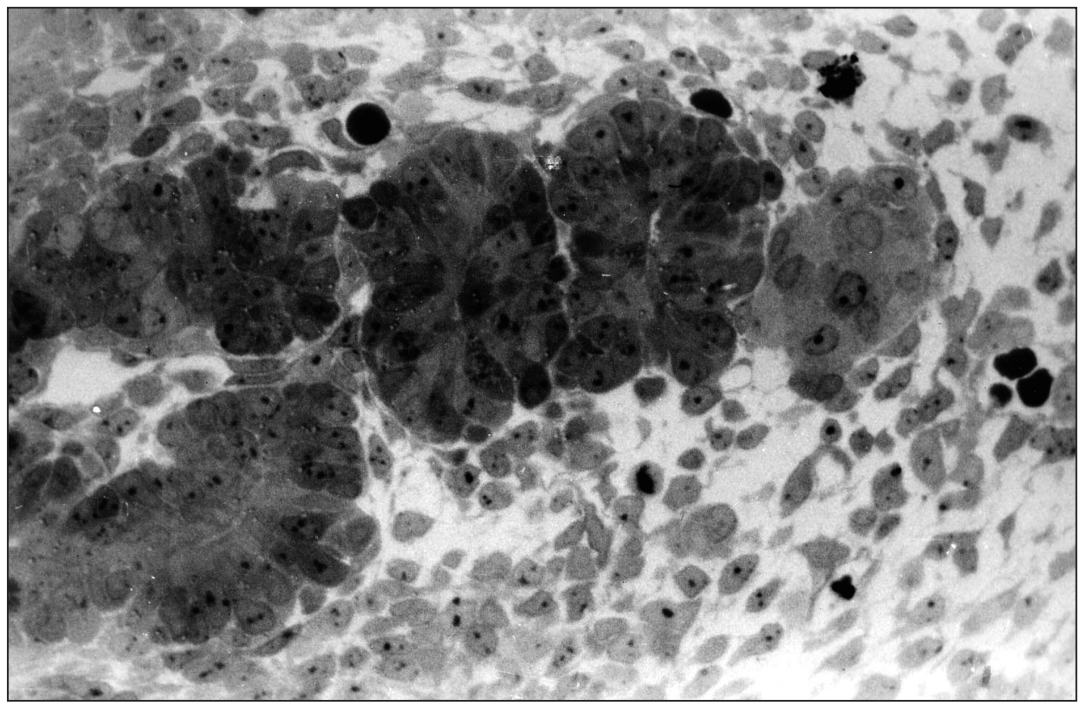

Fig. 3. Rabbit $11 \mathrm{~d} 14$ h. The anlagen of dorsal pancreas in semi-thin section. A group of lighter cells is lying at the end of pancreatic tissue. Darker pancreatic cells are adjacent to the duodenal lumen. Semi-thin section; staining Azur B. Magnification $\times 300$

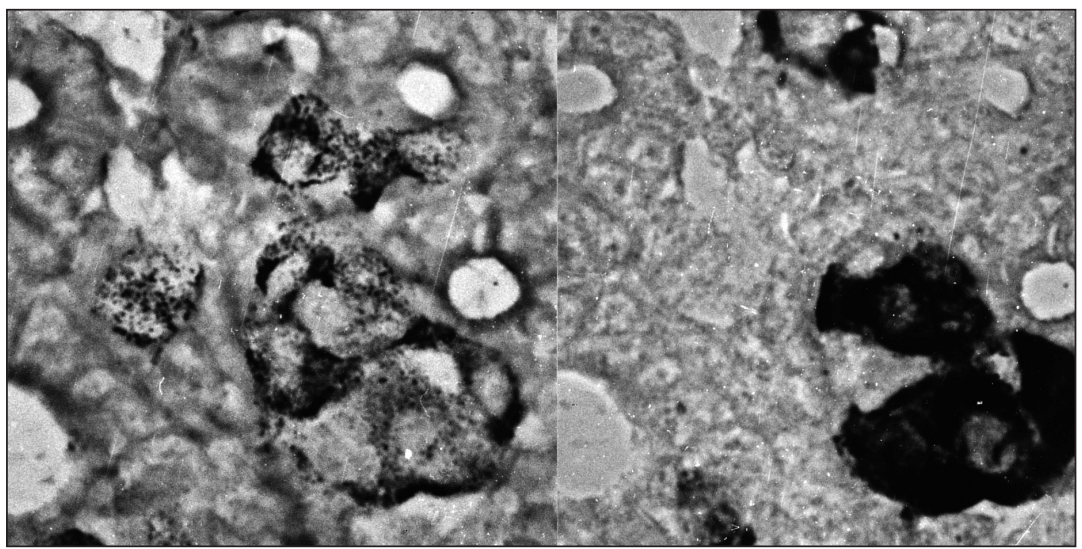

Fig. 4a. Rabbit $18 \mathrm{~d}$. Pancreatic tissue in the first picture is stained by method according to Grimelius, in the second one immunohistochemical detection of glucagon was performed. Some cells are Grimelius-positive and glucagon-negative cells, whereas others are Grimelius- and glucagonpositive cells or Grimelius-negative and glucagon-positive cells. Magnification $\times 300$ 


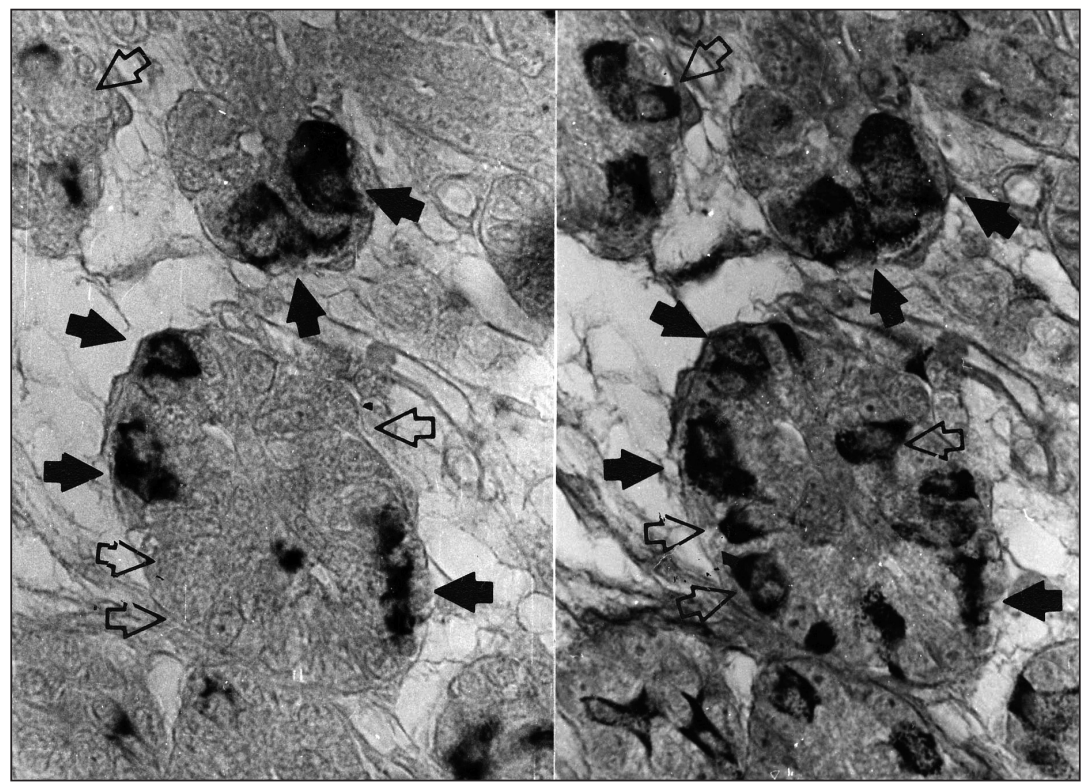

Fig. 4b. Rabbit 21 d. Pancreatic tissue in the first picture is stained by method according to Grimelius, detection of insulin was used in the second one. Many cells were Grimelius-positive and coincidently insulin-positive, whereas Grimelius-positive and insulin-negative cells are rare. Endocrine cells are present at this stage predominantly in the alveolar part of pancreas. Magnification $\times 300$

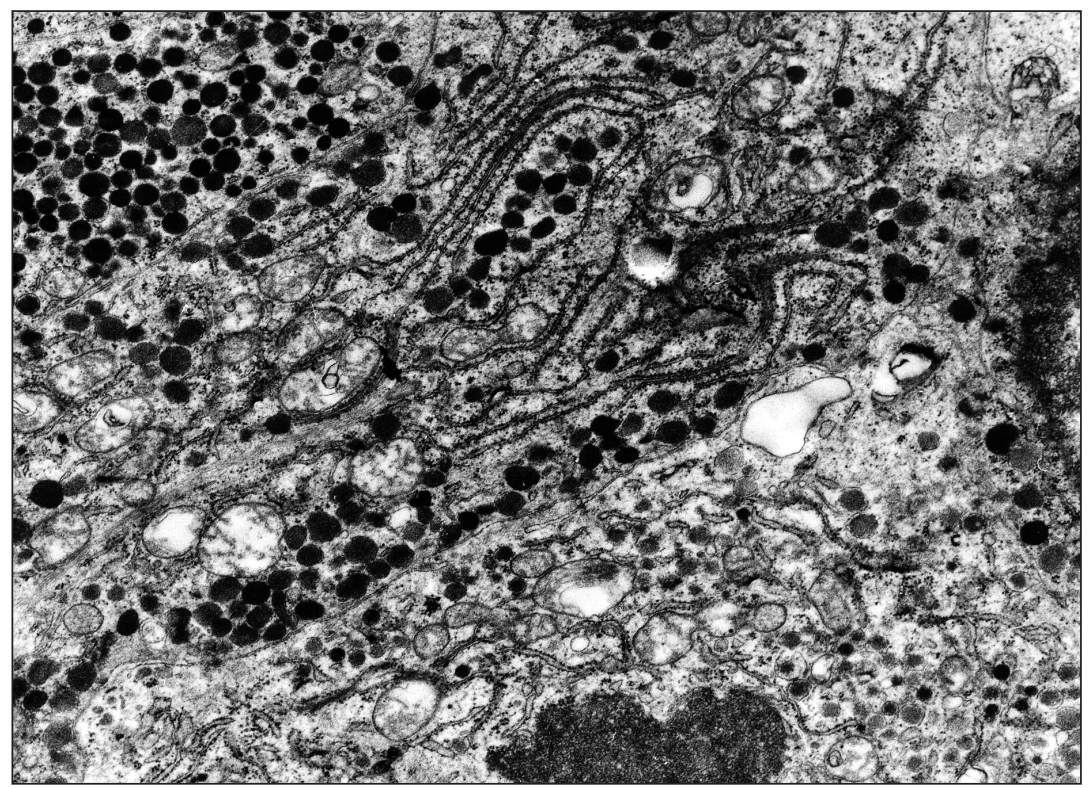

Fig. 5. Rabbit $27 \mathrm{~d}$. Mitosis in a young B-cell. The adjacent cell comprises dense larger granules lying near under the cellular membrane (probably a D-cell). Electron microscopy. Magnification $\times 15000$ 
